\title{
EMma NOZZI, SCHOOL TEACHER AND PROVINCIAL COLLECTOR (Buenos Aires, Argentina)
}

\author{
María Alejandra Pupio \\ Department of Humanities, Universidad Nacional del Sur \\ mapupio@uns.edu.ar
}

\begin{abstract}
The practice of archaeology in Argentina involved the participation of provincial amateurs who played a relevant role in the search, collection and exhibition of findings until the mid-twentieth century. This paper analyses Emma Nozzi's practices as a collector and provincial amateur scientist during the decades of the 1940s and 1950s, focusing especially on her gender and the less frequent participation of women in the social network of collectors in the province of Buenos Aires at that time.
\end{abstract}

Keywords: gender-collector-school teacher-museum-state knowledge

\section{Introduction}

In 1945 Emma Nozzi, a schoolteacher from Carmen de Patagones, wrote to Milcíades Vignati, Head of the Anthropology Department at the La Plata Museum In her letter Ms Nozzi, a sixth-grade primary schoolteacher, informed him that she had founded the Commission of Archaeological Studies called Quintuntchenque, which had assembled a collection of approximately a hundred pieces. She also sent him the school newspaper written by her

\footnotetext{
${ }^{1}$ Carmen de Patagones is located $937 \mathrm{~km}$ southwest from the city Buenos Aires. According to the 1947 National Census there were 15,287 inhabitants, 5,423 in the urban area and 9,864 in the rural area. From: Presidencia de la Nación, IV Censo General de la Nación. Resultados Generales del Censo de Población, (Buenos Aires: Dirección Nacional de Servicios Técnicos del Estado, 1951).
}

HoST - Journal of History of Science and Technology 10, pp. 11-32 DOI 10.1515/host-2016-0002 
students including interviews of indigenous people. This dispatch signalled the beginning of a relationship that would last until 1951. Far from being an isolated case, the relationship between Emma Nozzi and Milcíades Alejo Vignati depicted the modus operandi applied by archaeologists from Argentine institutions during the first half of the twentieth century to keep in contact with amateurs and province collectors ${ }^{2}$ From the early works of Robert Stebbins, over thirty years ago, a perspective of study of the history of science focused on the relationship between professional and amateur practices ${ }^{3}$ Consequently, this generated a vast historiographical production, which studied amateurs, their interaction with scientific and professional communities and their contribution to science. These works have allowed us to claim that science is a cooperative and collective entrepreneurship with a transnational structure to exchange objects, images and information, which requires a group of agents with different degrees of intervention to be developed. In this context, the role of amateurs in the conformation of archaeology constituted a widely studied phenomenon during the nineteenth century, at both national and international levels. Patrick McCray points out that, even when these practices were familiar in the nineteenth century, they seemed almost invisible in the twentieth century, due to the traditional view of the so-called professionalization of the sciences 4 Nevertheless, even in the last century, the division between professional and amateur scientists was not as strong as it was claimed. In Argentina, the perspective of a history of archaeology based on scientific practices shows it was not until the end of the 1950s that the discipline included a systematic participation of amateurs, whose role, far from being passive, was essential to the possibility of developing new knowledge about the past of local communities.

Emma Nozzi was part of a network of collectors and amateurs from the southern region of the province of Buenos Aires who actively participated in the search for data and collection of archaeological objects during the

\footnotetext{
${ }^{2}$ Milcíades Alejo Vignati (1895-1978) graduated as a schoolteacher in 1915 and as a Science teacher in 1918. He worked at the Faculty of Philosophy and Letters at University of Buenos Aires UBA until 1930 and from that moment until his retirement in 1957 at the National University of La Plata, where he acted as Professor of Anthropology and Head of Department of Anthropology.

${ }^{3}$ Robert Stebbins, "Toward amateur sociology: a proposal for the profession", The American Sociologist 13 (1978): 239-247; Robert Stebbins "Avocational science: The Amateur routine in Archaeology and Astronomy," International Journal of Comparative Sociology 21 (1980): 34-48; Robert Stebbins "Amateur and Professional Astronomers: A study of their interrelationships," Urban Life 10 (1982): 433-454.

${ }^{4}$ Patrick McCray, "Amateur scientists, the International Geophysical Year, and the ambitions of Fred Whipple," Isis 97 (2006): 634-58.
} 
1940s and 1950s. Furthermore, she collaborated in the arrangement of the logistics involved with the access to archaeological sites, and the display and conservation of collections exhibited to the general public in the various towns of the province. Alongside her colleagues, she was an active supporter and the first director of the Museum of Carmen de Patagones, which was set up thanks to her own collections. In this way, not only did these enthusiasts perform their amateur practices, but also, they played the role of civil servants, promoting a body of state knowledge derived from their work in archaeology and museology to a bureaucracy.

From a gender-related perspective, this study proposes an analysis of the presence of asymmetries in the role of women and men within school and museum settings. In this respect, the focus lies on understanding the practices of Emma Nozzi as a collector, keen on archaeology and history, and as a museum director, in a field ruled mainly by men, to study the connection between her female condition and her role in the social networks of collectors and amateurs. The interrelationship between the proposals of the history of science and of gender studies allows us to highlight a dual situation. On the one hand, the inclusion of Emma Nozzi in a collective of amateurs and collectors, recently incorporated in the history of the sciences in Argentina, and on the other, her participation as a woman in that group, with rules mainly laid down by men $5^{5}$ In addition, this study focuses on the social, political and personal conditions that enabled and allowed a woman from the province of Buenos Aires to act as an enthusiast in archaeology and history and as an expert in museology during the 1950s. The relationship between her teaching background and her public participation will also be addressed, by considering the tools to gain access to scientific information and to specific cultural products.

The study is carried out by cross-checking disciplinary fields with different degrees of development in Argentina. As mentioned above, it is related to the history of museums and the practice of archaeology in the first half of the twentieth century ${ }^{6}$ However, in connection with this perspective

\footnotetext{
${ }^{5}$ Ilana Löwy, "Ciencias y género" in Diccionario crítico del feminismo, ed. Helena Hirata, Francoise Laborie, Hélène Le Doaré, Danièle Senotier (Madrid: Editorial Síntesis, 2002), 41-46; Irina Podgorny "Emma B. Documentos para servir al estudio de la estructura familiar de los coleccionistas de fósiles: el caso de Emma y Auguste Bravard," Cuadernos PAGU 7 (2006), 479-495.

${ }^{6}$ The development of these studies in Argentina started in the 1990s with the works of Irina Podgorny, concerning scientific practice and areas of knowledge from the end of the nineteenth century and the beginning of twentieth century. From the existing vast bibliography we can mention Irina Podgorny and Maria Margaret Lopes, "Trayectorias y desafíos de la historiografía de los museos de historia natural en América del Sur," Anais
} 
and focusing on the role played by provincial town amateurs, it takes into consideration recent historical studies on cultural production in those local spaces.7 In this context, the study of "provincial intellectuals" or "culture promoters" has gained particular strength, applying Raymond Williams' category to study the role played by priests, teachers, journalists and town amateurs 8 To conclude, this work has been enhanced by recent studies on state knowledge and practice during the modernization process of Argentina in the first half of the twentieth century. These studies allow us to understand the forms of archaeological knowledge in connection to the creation of state expert groups, to comprehend the process by which part of this group of collectors and amateurs continued performing these activities as public servants 9

\section{Emma Nozzi's school practices}

Emma Nozzi (1 November 1917-27 December 1999), daughter of Italian immigrants, graduated from Escuela Normal Nacional in the city of Viedma, in the province of Río Negro, and worked as a teacher from 1937 at Escuela San Martin № 8 in Carmen de Patagones. As it was the case of many female teachers from the first half of the twentieth century, she did not marry and always lived with her mother ${ }^{10}$ From the end of the nineteenth century, Argentine primary school teachers used to get their degree at teacher-training

do Museu Paulista 21 (2013), 15-25; Irina Podgorny, El argentino despertar de las faunas y de las gentes prehistóricas. Coleccionistas, museos y estudiosos en la Argentina entre 1880 y 1910, (Buenos Aires: Eudeba/Libros del Rojas, 2000); Irina Podgorny, "Antigüedades incontroladas. La arqueología en la Argentina, 1910-1940," Intelectuales y expertos. La constitución del conocimiento social en la Argentina, ed. Federico Neiburg and Mariano Plotkin (Buenos Aires: Paidós, 2004), 147-174.

${ }^{7}$ Ricardo Pasolini "Prólogo" in Intelectuales, cultura y política en espacios regionales de Argentina (siglo $X X$ ), ed. Paula Laguarda and Flavia Fiorucci (Rosario: Prohistoria Ediciones, 2012), 11-20.

${ }^{8}$ Flavia Fiorucci, "Presentación" and "Los otros intelectuales: curas, maestros, intelectuales de pueblo, periodistas y autodidactas, prismas," Revista de Historia Intelectual 17 (2013):165-168.

${ }^{9}$ Ben Mariano Plotkin and Eduardo Zimmermann, "Introducción. Saberes de Estado en la Argentina, siglos XIX y XX," in Los saberes del estado, ed. Ben Mariano Plotkin and Eduardo Zimmermann (Buenos Aires: Edhasa, 2012), 9-28; Ben Mariano Plotkin and Eduardo Zimmermann, "Introducción," in Las prácticas del estado. Política, Sociedad y Elites Estatales en la Argentina del siglo XX, ed. Ben Mariano Plotkin and Eduardo Zimmermann (Buenos Aires: Edhasa, 2012), 9-34.

${ }^{10}$ Graciela Morgade, ed., Mujeres en la educación. Género y docencia en la Argentina 1870-1930 (Buenos Aires: Miño y Dávila, 1997), 94. 
colleges called Escuela Normal, a public institution that enabled them to obtain a complete repertoire of cultural consumption choices and practices 11

The expansion of the teacher-training career favoured a rapid entry of women into the teaching profession, reaching $85 \%$ during the first decades of the twentieth century. Despite this figure, the teacher-training career transmitted a hegemonic gender model. Men held the majority of the high secretarial and ministerial posts whereas women were schoolteachers or heads. Nevertheless, some teachers were able to criticise or confront this model. Training and teaching practice offered them certain emancipating elements, such as study trips, job opportunities in places far from their hometowns, union membership, out-of-school activities like reading clubs, and allowed some of them to publish. Therefore, even when teaching reaffirmed female stereotypes, it was also the means by which women from the urban petite bourgeoisie were able to achieve a certain degree of economic and intellectual emancipation and to gain ground in the exercise of power.12

This was the context that allowed Emma Nozzi to access a professional career, a job and a place in the public space of Carmen de Patagones in the 1930s. Her training and her first years in the profession were defined by the impact of the pedagogical approach called "Escuela Nueva" 13 This progressive pedagogical movement, based on learning through active enquiry, envisaged school as a laboratory of practical pedagogy that acted as a bridge between family and social life, promoting activities in the child's natural environment, such as study field trips to observe nature, manual work like carpentry, farming and raising small animals ${ }^{14}$ Such theoretical training influenced her school practice. She understood that the school was expected to promote children's participation and their central role in the making of decisions regarding learning, a process which did not end in the

\footnotetext{
${ }^{11}$ Flavia Fiorucci, "Las escuelas normales y la vida cultural en el interior: apuntes para su historia," in Intelectuales, cultura y política en espacios regionales de Argentina (siglo XX), ed. Paula Laguarda and Flavia Fiorucci (Rosario: Prohistoria Ediciones, 2012), 131-152.

${ }^{12}$ Silvia Yannoulas, "Maestras de antaño: ¿mujeres tradicionales? Brasil y Argentina (1870-1930)," in Mujeres en la educación. Género y docencia en la Argentina 1870-1930, ed. Graciela Morgade (Buenos Aires: Miño y Dávila, 1997), 176-177.

${ }^{13}$ Decroly, Montessori and Dewey's pragmatism and philosophies influenced and sustained this method in Argentina. It was also called "active school" because of the significance of Adolphe Ferrière and Edouard Claparède's ideas.

${ }^{14}$ On the impact of these ideas in Argentina, see: Sara Jafella, "Escuela Nueva en Argentina y Brasil: retrospectiva de un ideario pedagógico en la formación docente," Revista de Pedagogía, 23 (2002): 333-344; Ovide Menin, "Encuentro Binacional 'Escuela Nueva en Argentina y Brasil. Estado de arte y perspectivas de investigación," Escuela Nueva en Argentina y Brasil. Visiones Comparadas, ed. Silvina Gvirtz (Buenos Aires: Miño y Dávila, 1996).
} 
constraints of the classroom. Therefore, she considered that students needed to be educated as responsible subjects accountable for their actions through self-discipline. This would be attained by fostering freedom of movement in the classroom, which facilitated autonomy in decision making and critical thinking ${ }^{15}$

It is within such a pedagogical context that the interviews of indigenous people conducted by children must be interpreted, alongside the field trips to collect archaeological material to assemble the school collection. This was not a novel resource in Argentine schools since school museums were devices that came into use in the late nineteenth century. However, these devices crystallized in the 1930s from the experiences conducted in earlier decades. During the 1930s the concept of region gained strength as an articulator of such institutions and as an encompassing category in opposition to the creation of encyclopaedic collections, characteristic of school museums that had developed since the last decades of the nineteenth century. In the 1930s, sets of instructions for children on how to collect eggs, nests, insects and other small animals, the creation of regional herbariums and courses on taxidermy techniques became particularly popular ${ }^{16}$ At the same time, schoolteachers got in contact with lecturers and professors at universities in La Plata and Buenos Aires to request advice, technical support, materials and publications for their school museums. Thereby, reciprocity mechanisms were established, through which teachers supplied data and materials required by these professionals.

Beyond the good fortune and continuity of these experiences, the expansion of their use in school environments had the virtue of creating an audience that consumed these cultural and scientific proposals. School museums and field trips instructed children and teachers on the scientific practices of the time, turning them into effective collaborators of scientists, since the former had the necessary local knowledge and lived near the places where samples of flora, fauna, minerals and archaeological objects were collected. This took place in a broader social context during the 1930s, when a large fraction of people had access to scientific education through the dissemina-

\footnotetext{
${ }^{15}$ Interview to Emma Nozzi conducted by Alejandra Pupio, 12 August, 1997, Carmen de Patagones.

${ }^{16}$ Susana García, "Museos escolares, colecciones y la enseñanza elemental de las ciencias naturales en la Argentina de fines de siglo XIX," História, Ciências, Saúde-Manguinhos 14 (2008) 497-521; Susana García, "Museos y materiales de enseñanza en la Argentina (1890-1940)," in El museo en escena, ed. Américo Castilla (Buenos Aires: Fundación TYPA y Paidós entornos, 2010), 91-109; Susana García and Irina Podgorny "Pedagogía y nacionalismo en la Argentina: lo internacional y lo local en la institucionalización de la enseñanza de la arqueología," Trabajos de Prehistoria 58 (2001): 9-26.
} 
tion of scientific works, news articles and interviews about the development of Argentine archaeology in national newspapers, radio programmes, and the expansion of tourism for the elite and later of the working classes.

\section{From school collections to city museums}

Simultaneously and closely related to the growth of a consumer audience of scientific and cultural activities in the school environment, the number of museums in provincial cities increased. These experiences took place in the first decades of the twentieth century together with the creation of museums in the capital cities of provinces like Entre Ríos, Corrientes, Córdoba, Mendoza, Santa Fe, Tucumán, Salta and Santiago del Estero, especially designed as supplementary to the educational system ${ }^{17}$ Regional and historical-colonial museums actively spread throughout the country from the beginning of the 1930s, emphasizing the regional character of their collections, which included natural, archaeological, ethnographic and historical samples and objects. During the 1940s and 1950s, the process of museum creation gained distinctive characteristics in the province of Buenos Aires. In fact, since the foundation of the first city museum in 1872 until the end of the 1940s, only seventeen museums had been opened, while in the following decade nine state and six private museums were established 18 Among these institutions, some included historical, archaeological and natural science collections, while others exhibited theme and fine arts collections. Except for artistic or theme museums, the rest were called museums of history or natural sciences or the combination of both, and many of them included the term regional

Many of these museums came into existence thanks to city collectors and amateurs who transferred their private collections and became directors of those institutions 19 , These collections had their origin in field collection. Emma Nozzi and the other collectors had sound knowledge of the region that led them to explore the area systematically in search of sites, which they considered spots in the landscape containing remains of aboriginal culture ${ }^{20}$

\footnotetext{
${ }^{17}$ García, "Museos provinciales," $77-81$.

${ }^{18}$ Ministry of Education Catálogo de museos, monumentos y lugares históricos de la provincia de Buenos Aires (La Plata: Ministerio de Gobierno de la Provincia de Buenos Aires, 1979).

${ }^{19}$ Alejandra Pupio, "Coleccionistas de objetos históricos, arqueológicos y de ciencias naturales en museos municipales de la provincia de Buenos Aires (Argentina) en la década de 1950," História Ciências Saúde-Manguinhos 12 (2005): 205-229.

${ }^{20}$ The archaeological materials that were recovered on these field trips constituted con-
} 
A significant part of the collectors' activities was oriented to locate these sites to systematize and photograph them, collect material, catalogue and exhibit it, to develop a regional map with the occupied areas. The activity was based on the surface collection of objects, which were assessed as formal artefacts. Therefore, these collections were made up by a set of pieces including milling devices, projectile points, bolas, pottery and scrapers. Every single item was catalogued according to its morphology, obtaining subsets: bolas with and without grooves, hafted and unhafted bifaces, etc. The aim was to produce a new type to avoid an overload of similar pieces. Consequently, an excess of repeated items was generated, which were eventually exchanged or sold. These pieces were gifts or exchanged among collectors, which strengthened and merged their sociability and fellowship.

It was due to her training in the teaching career that Emma Nozzi was able to develop and implement the practice of data collection since she considered that learning could not be restricted to the physical and architectural boundaries of the school environment. Her aim was to connect the children from Carmen de Patagones with their natural and social environment. She was especially concerned about the citizens' lack of knowledge regarding native history and culture, which could easily be discovered by walking and observing the rural areas on the outskirts of town. Thereby, and encouraged by the school head, she performed different participatory experiences to widen the children's vision beyond school and family. As a consequence of these educational practices, the teacher published a school newspaper, which included interviews to indigenous people, and produced an archaeological collection. This publication, sent to the Museum of La Plata, aroused Milcíades Alejo Vignati's interest due to the information it contained, and it signalled the beginning of a relationship with Emma Nozzi, which would broaden her participation and place her in a network of relations beyond the local boundaries.

Their contact endured and with Vignati's advice, approval and commendation, the teacher continued collecting materials and information. As Nozzi broadened her knowledge about archaeology and the history of Carmen de Patagones, the relationship mainly focused on technical assessment

crete evidence of prehispanic indigenous societies. The population in the south of the province of Buenos Aires and Río Negro during the first half of the twentieth century came mainly from Italian and Spanish migrations. The indigenous population was fundamentally made up by the Mapuche people, rearranged due to military occupation at the end of the nineteenth century. As the European population rapidly occupied the political, economic and social spaces in these lands, the indigenous societies were relegated to the outskirts of the cities and to the countryside.

HoST - Journal of History of Science and Technology 10, pp. 11-32 DOI $10.1515 /$ host-2016-0002 
offered by the professor in connection to collection management and future museums, and on the requests the anthropologist submitted to the teacher. The latter referred to the spotting of new archaeological sites and to specific topics he was studying, regarding aboriginal skulls and gualicho trees. Indigenous people used to pay tribute to these trees at the roadside to prevent them from suffering the evil power of the Gualicho spirit ${ }^{21}$

Emma Nozzi acted as an intermediary locating pieces such as indigenous skulls and flint axes, which were at neighbouring houses in the town 22 Once she located them, she persuaded the owners to give them on loan to the Museum of La Plata in order for the professor to make moulds for academic study. At times these transactions created a tense situation due to the researcher's delay in the return of the pieces and the neighbours' complaints, which Emma had to soothe, since, on occasions, Vignati took several years to send them back. Nozzi proved to be and an efficient and cooperative provider before the professor's requests, which would bring about a relationship that exceeded the archaeological issues and included the archaeologist's concern, and intervention as school head Teresa Rucci was removed from her duties when Peronist governor Víctor Mercante took office in the province of Buenos Aires (1946-1951). Gradually, the relationship became more affectionate and caring, as when the professor expressed his enthusiasm at Emma's finding of a gualicho tree and the Gualicho Lowland in 1951, "taking for granted you are neither going to misunderstand me nor take this as a flirtatious remark, when I tell you wholeheartedly that you are absolutely charming, no more no less: a charming person.'23 Likewise, at the time when the teacher requested the professor to visit Carmen de Patagones to assess the surveyed sites she had located, Vignati answered that he had not lost "hope to see you and speak to you; I can interpret feminine wishes as orders, and therefore I must go: I'll wander through this place I've been in

\footnotetext{
${ }^{21}$ Southamerican ethnic groups such as Tehuelches and Mapuches believed in Gualicho, a type of evil spirit. In order to avoid the power of Gualicho aborigines paid him tribute under Gualicho trees by the side of the road in a large depression under the sea level called the Great Gualicho Lowland. Among the naturalists and travellers who mentioned the tree in their records we find Charles Darwin, who visited the region in 1833.

${ }^{22}$ Collectors' activities were ruled by National Law $\mathrm{N}^{\circ}$ 9080, passed in 1913 and enacted in 1921, according to which, ruins, archaeological and paleontological sites were declared property of the nation. It also allowed the Ministry of Justice to grant licences to national and foreign scientific institutions to use and exploit these sites under the counselling of the National Natural History Museum, the Ethnographic Museum of the Faculty of Philosophy and Literature of the University of Buenos Aires and the Museum of La Plata.

${ }^{23}$ Letter from Milcíades Vignati to Emma Nozzi, March 18, 1951, Administrative Archive, History Museum Emma Nozzi (AAMHEN).
} 
love with for a quarter of a century.'24

Undoubtedly, the removal of the head of the school affected Nozzi emotionally, producing a "state of indifference towards all I cared for until that moment." 25 The changes that occurred following 1946 with the new school head meant a halt to the activities pertaining to the school collection. In 1951, school head Dámaso O. León opposed to and hindered the transfer of the materials donated to the museum, which were in a state of abandonment and carelessness. This institutional internal affair and the impossibility of carrying out her teaching duties the way she was accustomed to, pushed her to seek a job opportunity in a new museum project. From that moment onwards, she found refuge in her epistolary relationship with Milcíades Vignati, who periodically shared with her articles he had written himself. These writings she considered essential since they opened "doors to escape for long hours from this stupid reality that surrounds me." 26 Without the intellectual motivation that used to arise from school, she devoted herself to build an archaeological collection and to seek cooperation from willing neighbours and local politicians to obtain historical objects and to create a museum for her town, like those existing in other places of the province.

Through a sustained and systematic exchange of letters, Nozzi informed Vignati of new findings and provided him with the requested information. Vignati based his interest in the relationship with Emma Nozzi on the possibility of gathering information and logistics to organise exploration trips and of the periodic provision of objects, relevant to his research work. The largest part of the archaeological production of the southern coast of Buenos Aires was based on the description of isolated objects that did not require context information and discovery details because they were materials from surface collections in national museums or private collections. These were rare findings and discoveries associated with ceremonial and religious activities, such as stone axes, engraved plaques and painted skulls.

Vignati's production was modelled from the data given by amateurs and by the possibility of keeping in contact with neighbours, due to the position he held as Chief of the Department of Archaeology of the Museum of La Plata. The data provided by Emma Nozzi, as that of other enthusiasts who contacted Vignati, was published in reports of findings. Particularly in the case of the finds in the area of Carmen de Patagones, the professor published studies on a human skull hit by a projectile Emma Nozzi had sent to La

\footnotetext{
${ }^{24}$ Letter from Milcíades Vignati to Emma Nozzi, March 18, 1951 (AAMHEN).

${ }^{25}$ Letter from Emma Nozzi to Milcíades Alejo Vignati, July 6, 1946 (AAMHEN).

${ }^{26}$ Letter from Emma Nozzi to Milcíades Vignati, September 4, 1949 (AAMHEN).
} 
Plata, which was part of a private collection from a neighbouring city ${ }^{27}$ As with other cases, collectors and neighbours were acknowledged for their loan, donation or contribution. Therefore, Vignati developed his writing from the findings and information amateurs put at his disposal 28 Thus, he bridged the gap between the field and the laboratory or museum and the shortage of professionals, creating a net of collaborators and correspondents ${ }^{29}$ A new topography of knowledge being developed in areas of different levels of knowledge was constituted, amidst alliances and disputes ${ }^{30}$

The relationship between Nozzi and Vignati was not limited to a mere liaison between a data supplier and an academic. When Nozzi trespassed the school limits and took part in the public space to foster the creation of the city museum, she found in Vignati the person who would introduce her to the professional practice at such institutions. The fact that the Peronist government had initiated a new organization relating to cultural management acted as a triggering event that paved the way for her to achieve her goal. The reform of the Buenos Aires Constitution in 1949 meant a change in the institutional structure that governed educational and cultural management. The Ministry of Education was created and this administrative structure included the Department of Museums (1950), which encompassed the four existing museums in the province and promoted the creation of new ones ${ }^{31}$ Likewise, department officials established and maintained open lines

\footnotetext{
${ }^{27}$ Milcíades Vignati, "Contribuciones al conocimiento de la paleopatología argentina. X Cráneo humano flechado del litoral sud bonaerense," Nota del Museo de La Plata 12 (1947): 77-81.

${ }^{28}$ Alejandra Pupio, "Coleccionistas, amateurs y arqueólogos en la conformación de las colecciones arqueológicas del Museo de La Plata, Argentina (1930-1950)" in Coleccionsimos, prácticas de campo e representações, ed. Maria Margaret Lopes and Alda Heizer (Campina Grande: EDUEP, 2011), p. 274.

${ }^{29}$ Irina Podgorny, El sendero del tiempo y de las causas accidentales. Los espacios de la antigüedad del hombre en el Plata, 1850-1910 (Rosario: Prohistora, 2009).

${ }^{30}$ David Livingstone, "The spaces of knowledge: contributions towards a historical geography of science," Environment and Planning D: Society and Space 13 (1995): 5-34; David Livingstone, Putting Science in Its Place: Geographies of Scientific Knowledge (Chicago: University of Chicago Press, 2003); Simon Naylor, "Introduction: historical geographies of science-places, contexts, cartographies," British Journal for the History of Science 38 (2005): 1-12.

${ }^{31}$ María Élida Blasco, "La fundación del Museo Colonial e Histórico de la Provincia de Buenos Aires. Cultura y política en Luján, 1918," Boletín del Instituto de Historia Argentina y Americana Dr. Emilio Ravignani 25 (2004): 89-119; María Élida Blasco, "Los museos históricos en la Argentina entre 1889 y 1943," in XI Jornadas Interescuelas / Departamentos de Historia (Tucumán: 2007); María Élida Blasco, Un museo para la colonia. El Museo Histórico y Colonial de Luján 1918-1930 (Rosario: Prohistoria, 2011); María Elida Blasco, "La formación del Parque Evocativo y Museo 'Los Libres del Sur'
} 
of communication with local museums in the province, supplied information, offered management consultancy, and implemented the Census of State Patrimony (1953) for museum pieces, to enable the assembly of an inventory of the existing pieces in provincial museums.

The relationship with officials from La Plata was made possible since the mayor of Carmen de Patagones, Carlos Tessari (1946-1951) was a member of the Peronist Party and travelled regularly to La Plata on administrative matters. Due to the relation between local politicians and those from the province capital city, Emma could establish a lasting friendly relationship with Herbert Smith, secretary of the Department of Museums, who soon became her second professional and personal counsellor. And from 1950 they sustained a cordial and polite correspondence, as was also the case with Vignati, which not only comprised technical reports, but also included personal conversations about family life, work, health, among other topics, since Smith felt it was necessary to go beyond cold and impersonal letter writing and transpose it into "intellectual or spiritual correspondence." 32 In that sense, the official stated, in more than one instance, the relationship they had established, and whenever Emma apologised for taking up his valuable time with her letters, he replied "how anxiously I look forward to them every time I write, and I don't just read them once. I don't waste time; I gain spiritual peace, learn, receive your suggestions, I gain optimism and friendship." 33

Smith and Vignati continually advised Emma on technical museum management, regarding documentation, preservation and inventory. She followed those instructions, which led to the organization of a committee to foster the museum foundation (Comisión Pro Fundación del Museo) and to the creation and opening of the Museum of Regional History Francisco de Viedma in July 1951, with 3,000 specimens in its collection. As Honorary Director, she continued her epistolary relationship with the professor and the official: the former advised her on how to index and classify pieces and gave her instructions later on how to catalogue them; the latter suggested shapes and sizes of display cases, guided her in the tagging of specimens, and above all, instructed her in the technicalities of the Census of State Patrimony since 1953. The instructions and advice given by Vignati and Smith had trained Nozzi in technical issues; but it was her training and teaching practices that defined the relationship she established between the

(Dolores, 1939-1942)," Cuadernos del Sur-Historia 39 (2010): 9-36.

${ }^{32}$ Letter from Herbert Smith to Emma Nozzi, 4 June, 1951 (AAMHEN).

${ }^{33}$ Letter from Herbert Smith to Emma Nozzi, 31 August, 1951 (AAMHEN). 
museum and the public. Emma considered the museum a school, so "if the museum isn't a school, if it doesn't communicate, it's useless," and therefore fostered educational activities which would complement those carried out in the classroom 34

The field of state administration and professionalization of museums in the 1950s did not include many women. City museum directors were almost only men, public officials and managers in provincial units, and political officials in local councils were also men. Emma was a museum director in a social space ruled by men. She established an asymmetric relationship with her mentors Vignati and Smith, playing the role of an apprentice, learning about rules and regulations, and technical, administrative and political procedures. Both the professor and the provincial official encouraged her because as Smith stated "I've met few teachers able to develop this task so proficiently."35 In this sense, the teacher established a hierarchical relationship, in which she received advice, guidance, recommendations and requests from the professor and the province officer. Vignati and Smith advised her on specific readings, places to purchase furniture for the museum as well as suitable methodologies on how to carry out the inventory of the collections and their display. As an element in this long-distance relationship from La Plata, both adopted a paternalistic and protective attitude towards Emma, considering her exceptional nature in that professional world.

Education at the museum was the field where Emma made entrepreneurial and autonomous decisions. In this world of men where there were few cases like Emma's, similar traits can be found in Mercedes Aldalur (01-06-1885/51995), a school teacher from Chascomús, Director of the Pampas Museum of Chascomús since 1939. Nevertheless, they were not in contact during the period of study, since Aldalur had been removed from her position in January 1947 by the Peronist government from the province of Buenos Aires; she was later restored to her position in November 1955 after the coup d'état that ousted Perón. Mercedes had been a teacher of geography at Escuela Normal Superior since 1913, and from 1918, director and teacher of critical pedagogy at Escuela Normal de Subpreceptores. She took part in committees and civil associations, vocational theatre as director, and authored many books on American literature. ${ }^{36}$ In 1939 she joined the Honorary Commis-

\footnotetext{
${ }^{34}$ Interview to Emma Nozzi conducted by Alejandra Pupio, 12 August, 1997. Carmen de Patagones.

${ }^{35}$ Letter from Herbert Smith to Emma Nozzi, 4 June, 1951 (AAMHEN).

${ }^{36} \mathrm{He}$ published three literature works: Historias romanceadas de la Guardia de San Juan Bautista de Chascomús (1976); Un romance de amor bajo la tiranía (1979); Romances trágicos de la conquista. Una jornada a las Indias en tiempos de Carlos V. Romances de
} 
sion to build a park in memory of the patriots from "Free South" in Dolores and Chascomús ${ }^{37}$ This committee was made up by twelve members, citizens from both towns, including directors Nemesio Cabrera and Mercedes Aldalur, the only female member. Similarly to Emma and because of her teacher education, Mercedes considered that museums and libraries, like schools, were educational centres. Therefore, the exposure criteria should adjust to the pedagogical concepts and approaches ruling schools to develop a complementary effect.

\section{Women as collectors}

Similarly to Emma, many other provincial amateurs became public officials, holding positions as directors at these new institutions, due to their role as collectors or science amateurs, and they offered their own collections as foundations of these museums. Once they had become directors they continued their activities as collectors and amateurs. Thus, the practice of archaeology and museology became municipal knowledge, although, in order to understand their practices, it is important to consider Plotkin and Zimmerman, who point out that the state intervention must be interpreted as a grey zone defined by the existence of porous and fluent frontiers, spaces of circulation of ideas and individuals ${ }^{38}$ Therefore, in this case, even when within the state structure, these museums were border areas between state and non-state spaces. In this sense they shared the same field practices, preservation and display as those carried out by amateurs who owned private collections in their houses or private museums. This knowledge became public due to the process of expansion the state was undergoing, which required technicians able to manage these new state agencies, applying common standards and procedures. The practice of archaeology during the first half of the twentieth century coalesced with the state requirements and facilitated the constitution of a state elite, mainly composed of amateur scientists and provincial collectors, who rapidly and eventually became specialists in general management of the new museums. Two elements contributed to achieving this, on one hand, the lack of specific training in archaeology; and on the other,

\footnotetext{
Juan de Garay (1981).

${ }^{37}$ The Free South Revolution ("Revolución de los Libres del Sur"), was an uprising rural landowners and traders led against Juan Manuel de Rosas in 1839 during his second term of office as governor of the province of Buenos Aires (1835-1852). See: Jorge Gelman, Rosas bajo fuego. Los franceses, Lavalle y la rebelión de los Estancieros (Buenos Aires: Sudamericana, 2009).

${ }^{38}$ Plotkin and Zimmerman, "Introducción," 18.
} 
the existence of one tertiary career in museum technician training offered by University of Buenos Aires 39 Under such situation, the amateurs were the only capable individuals to establish knowledgeable groups with technical expertise required by and constitutive of a modern state 40

Tomás Bernard, Director of Museums and author of one of the first museology manuals written in Argentina, highlighted the impact of amateurism on museum management. He described the initial phase of these institutions and stressed the need to overcome that overgrown stage:41

(...) relying on goodwill, sporadically though, without group intent or vision, due to "amateurism" common to all beginnings. Our local and regional history museums were born thanks to the collections owned by amateurs and researchers, making use of what already existed in some cases, in a very precarious manner. They lived on the disinterest of a few enthusiasts and the devotion of many patriots, authentic saviours of our historical heritage. Thus, the hard stage of collecting material was completed, with love and sacrifice, preserving those collections from thousands of devastating and dispelling forces. Local museums emerged from determination and strong will, here and there, without plan or method, gathering their collections as they could, with heterogeneous and diverse materials, many a time, absolutely divorced from the dictates of science and technical norms.

New and varied social networks were developed in this universe, and collectors and amateurs took part in many of them simultaneously. Emma participated in many of them, such as the group composed of the directors of museums from the southwest of the province of Buenos Aires, and the one established by the Department of Museums, operating from La Plata. The first one was an informal relationship while the second was institutional. Both complemented each other since the provincial agency's activities favoured the contact between officials and amateurs.

Emma Nozzi started a non-institutional solidarity network of communication with the directors of city museums from southwest Buenos Aires, based on personal relationships. Every member held a relevant position in their own communities, such as journalists, general practitioners, traders,

\footnotetext{
${ }^{39}$ Pupio, "Coleccionistas de objetos históricos," 208.

${ }^{40}$ Plotkin and Zimmerman, "Introducción. Saberes de Estado," 10.

${ }^{41}$ Tomás Bernard, Experiencias en museografía histórica (Buenos Aires: Ediciones Anaconda, Buenos Aires, 1957), IV and V.
} 
lawyers or politicians, Emma being the only woman ${ }^{42}$ Although all the members had equal status, there existed a master?disciple relationship among its members. Such was the case of the Director of the History Museum of Bahía Blanca, $270 \mathrm{~km}$ north of Carmen de Patagones, who played the role of master and who was not only consulted in connection to museum management but also about decisions to be made regarding certain collections. This network was made possible because its members shared a common core of learning patterns, protocols of observation, sample collection, cataloguing and display. This was enriched by the extensive and sustained correspondence, which provided them with an opportunity to exchange bibliography, share information and participate in collective field trips. Besides, members shared the practice of writing, and some of them did it professionally as collaborators in local newspapers, while others were self-published authors. The wide range of themes included theatre plays, radio dramas, poetry, philosophical and fiction works. In the 1950s, works concerning local and regional history were published. Their main themes were nineteenth century aboriginal history and the founding of towns and cities of the province of Buenos Aires. Emma Nozzi wrote chronicles on specific topics pertaining to the history of Carmen de Patagones, using documents from the Historical Archive of the General Army Staff and the Department of History Study at the Ministry of War. In all the cases, the pieces resulted from their own fieldwork, exploration in libraries, archives, oral history, practices that must be interpreted as one of the many facets of the collecting experience.

Although writing was a shared practice, the account of aboriginal history had its overtones. While some authors highlighted the epic of military actions as a motor of growth and development, others focused on the indigenous heroism and their defeat in the name of a questioned modern age. In these works there is a clear distinction between tradition and modern age and the question whether indigenous and whites could have lived fraternally in the same geographical space. In all cases there was the inevitable need to write locally, especially in search of the origins of cities older than seventy years or those that had reached the century. In this sense, although Emma Nozzi acknowledged the process of modernization that came about as a consequence of the advance of the frontier to the south, she wondered whether there could have been a different ending to the fight between creoles and Mapuches through more humanistic ways than those that actually prevailed. ${ }^{43}$

\footnotetext{
${ }^{42}$ Pupio, "Coleccionistas de objetos históricos," 210.

${ }^{43}$ Emma Nozzi, Carmen de Patagones y la Guardia General Mitre (Carmen de
} 


\section{Emma and other women in a network of profession- als in training}

For the dubious and undetermined reason that might refer to the affectionate relationship between Smith and Nozzi, or to the predisposition of the mayor of Carmen de Patagones and his relationship with the politicians from La Plata, or even to the historical events the town evoked, the Museum of Carmen de Patagones held a place at the provincial administration that few local museums did. That was why, Herbert Smith engaged in the process of provincialization of the museum, so it played an important role in the project of regionalization of institutions under the Department of Museums, written by Smith in 1955 and directed by Tomás Bernard. However, the transfer to the provincial jurisdiction was eventually dismissed. The museum received constant support, especially until 1953, when Smith served as Secretary of the Museum Department. An expression of the importance of this institution was the choice of Carmen de Patagones as the venue for the First Provincial Congress of Historical and Regional Museums of the Province of Buenos Aires and Patagonia, held in January 1952 (Figure 1).

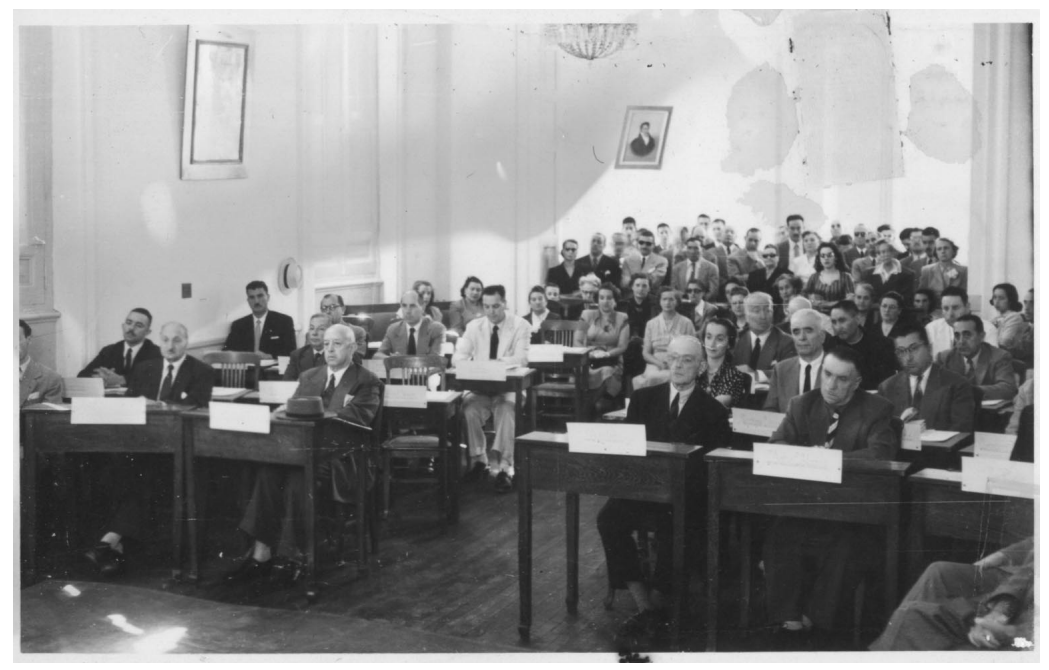

Figure 1: Session of The Congress of Historical and Regional Museums of the Province of Buenos Aires and Patagonia, held in January 1952. In the second row at right is Emma Nozzi, one of the two woman present in the meeting. Museo y Archivo Histórico de Bahía Blanca.

Patagones: Museo Histórico Regional Municipal Francisco de Viedma, 1962).

HoST - Journal of History of Science and Technology 10, pp. 11-32 DOI $10.1515 /$ host-2016-0002 
Institutions from Buenos Aires and from the provinces of Patagonia convened for this event because of the critical role played by the Department of Museums. The overall goal of the meeting was to "decide on a system of permanent cooperation and of technical and cultural exchange" among cultural institutions ${ }^{44}$ The congress included both a cultural and a technical agenda to be discussed. The first one included issues related to technical, administrative and cultural museum cooperation, such as information exchange to create a general database; donation and exchange of similar specimens; organization of history contests and competitions; promotion of cultural dissemination activities e.g. descriptive guides, documentaries, specialised libraries; training of technical personnel; fostering relationships between schools and museums. The technical agenda proposed to determine a uniform system for inventories, files, documents and photographs; to discuss major divisions of museum collections and museographic topics such as room lighting, display cabinets and showcases, files, framing, handling of objects; exhibition systems; storage and specialized preservation, conservation and restoration procedures; security systems and devices against fire or burglary; schemes to figure out the authenticity and market value of museum collections and individual museum specimens before their display.

The congress achieved the participation of 29 museum representatives from the province of Buenos Aires and Patagonia. Only three of them were women, namely the wife of the Director of the Maritime Museum who attended as a listener accompanying her husband, Emma Nozzi, and Ileana Lascaray (1926-2004). The latter was a single woman, also a primary school teacher from the city of Neuquén. The consulted documentation allows us to state she was the third woman to hold a position in museum management together with Emma Nozzi and Mercedes Aldalur in the extensive area including Buenos Aires and the provinces of Patagonia. Here Lascaray's public activity was related to the museum created in Neuquén. In 1948 the National Board of Education was organising a museum in that city, with objects donated by National School Inspector Daniel Gatica, which included specimens he had collected during field trips for the schools he worked at and materials his students had donated. There was a national call for applications for the post of Museum Director, to which Ileana Lascaray was appointed. After two years of service she was authorized by the Ministry of Education to travel to Buenos Aires for a temporary assignment where she

\footnotetext{
${ }^{44}$ Letter from Director of History Museums, Dr. Juan Beltrán to Luis Scalese, 21 August, 1951, Note 2091, Administrative Archive, History Museum of the Desert Campaign Conrado Villegas (AAMHCV).
}

HoST - Journal of History of Science and Technology 10, pp. 11-32 DOI 10.1515/host-2016-0002 
attended courses and trained in the museological area at the Ethnography Museum (University of Buenos Aires). When she returned to Neuquén she held different official positions in cultural management. Like Emma, until her death in 2014, Ileana was closely linked to the cultural initiatives and actions in the capital of the province, and was acknowledged as the "first female government official, when women did not use to work in that field. The media have told a great truth, I have paved the way for women in decision making in the province of Neuquén." 45

The meeting in 1952 was the starting point of a professional and personal relationship that would last the whole decade and which would include the request and offer of counsel, the exchange of objects and bibliography and shared field trips. It was a fruitful year for the relations among the representatives who attended the congress of Carmen de Patagones. In February Emma Nozzi would send notifications to the participants, in which she expressed that "undoubtedly, the friendly relationship?rooted in personal and direct knowledge?among representatives, will be one of the most outstanding results of the recent congress and will bring about the most considerable and significant fruits.'46

It is important to point out that this communication was maintained outside the official channels among institutions, creating a "spiritual link, far superior to written and official communications, since it leaves a wide scope for unforgettable memories.' ${ }^{47}$ This was made manifest in the intimate tone of the correspondence, which included greetings such as "dear friend" and reference to events in their private life or institutional issues, which would not be told to other mere officials. Besides, collectors sensed that, due to the friendly nature of the relationship, they would obtain substantial benefits for the museums they ran, since it allowed them to develop a link not confined to the administrative regulations, but on the contrary, based on camaraderie because "wherever there is a person who has been a representative at the already mentioned congress, there is a collaborator and a friend."48

Nevertheless, not all the subsequent experiences after this event proved satisfactory. Due to the attendance at the congress of scientists who were archaeology amateurs, Emma Nozzi seized the opportunity to upgrade them regarding the myriad materials at the coast, which appeared especially interesting for Antonio Garcés (1885-1971), school teacher and director of the

\footnotetext{
${ }^{45}$ Local newspaper La Mañana de Neuquén, "Writer and historian Ileana Lascaray has died", 11-06-2014. http://www.lmneuquen.com.ar/

${ }^{46}$ Letter from Emma Nozzi to Luis Scalese, 9 February, 1952 (AAMHCV).

${ }^{47}$ Carta de Luis Scalese to Emma Nozzi, 16 February, 1952 (AAMHCV).

${ }^{48}$ Letter from Frigate Captain Hugo Leban to Luis Scalese, 10 April, 1952 (AAMHCV).
} 
Patagonian Regional Museum of Comodoro Rivadavia and for Federico Escalada (1909-1959), general practitioner and representative of the Superior Institute of Patagonian Studies from that city, who was interested in ethnological studies. One month later, she received their visit and accompanied them on their field trip to the town of San Blás, where relevant finds took place. The collectors took all the materials, despite the requests made by the mayor of Carmen de Patagones to leave a sample for the local museum. Emma expressed her concern about the event to Smith, wondering whether they formed "an oasis of generosity and selflessness even within this group of men that seemed to give it all, driven by laudable human greatness?'49 Undoubtedly, this pretence of being a homogeneous collective of scientists, collectors, amateurs and museum directors belonged to rhetoric rather than to the real development of the established relationships. On the contrary, it was characterised by implicit asymmetries, which led Emma Nozzi to be identified as a manager and coordinator rather than as an amateur scientist, despite her efforts to gain such recognition.

Regardless of the place each collector, amateur or director held in these social networks, relations were fostered by the administration of museums of the province of Buenos Aires, through different channels of communication and exchange of information, which facilitated training in this field of study. Although the amateurs in managing positions at regional museums were not able to benefit from formal training proposals, the meetings about the specialty were widely accepted and attended. This was the case of the First National Meeting of Museology held in Buenos Aires in 1960, which was convened by the School of Museology from the University of Argentine Social Museum, to celebrate the 150th anniversary of the May Revolution. The board of directors was formed from representatives of the School of Museology, the International Council of Museums ICOM, national museums, and one museum from the province of Buenos Aires, General Conrado Villegas Museum, from Trenque Lauquen. Among the full members were the representatives of university museums, especially those from Buenos Aires and La Plata, a few delegates from the provinces of Catamarca, Córdoba, Corrientes, Chubut, Entre Ríos, Neuquén, Salta, Santa Fe, Tucumán and a large delegation from the province of Buenos Aires, which included provincial authorities and provincial museum officials, and two women, Emma Nozzi and Juana Elías de Mascheroni, an amateur historian who worked at the Historical Archive of the city of 9 de Julio.

At the end of the 1950s an increase in the professionalization of muse-

${ }^{49}$ Letter from Emma Nozzi to Hebert Smith, 11 February, 1952 (AAMHEN). 
ology centralised in the city of Buenos Aires could be observed, from which emerged a technical group of professionals, conformed by directors and professionals from national and university museums and university artists and researchers. This produced a growing differentiation between the new generation of professionals and the former group of state officials constituted by amateurs and provincial collectors. The new professional elite held university degrees, trained in Europe and the United States, and belonged to sociability networks that linked them to sectors with economic, political and intellectual power. This did not mean that the participation of collectors and amateurs in the creation, development and running of museums had less power. On the contrary, there are still museums in many provincial cities run by amateurs. As from the 1960s, the development of institutions became dissimilar and asymmetrical, sustained by exchange and circulation in spaces with uneven symbolic capital. The professionalization in the field of museology was contemporary with that of archaeology. The development of careers in anthropology at the universities of La Plata (1957) and of Buenos Aires (1958) required and trained qualified experts. As a consequence, amateurism was publicly condemned, even when its practice had helped establish a system of cooperation among professionals, collectors and amateurs. Nevertheless, this social disapproval did not mean the end of amateur practice, which remained part of the daily actions in provincial cities.

\section{Future agenda}

The universe of provincial collectors and amateurs between the decades of 1940 and 1950 was mainly composed of men who played a relevant role in their communities. These representatives would become museum directors as they donated their private collections to constitute the first heritage of such institutions. Therefore, the case study analysed in this work presents a singularity, since there has been little record of women as collectors and amateurs appointed directors of state museums. Besides Emma Nozzi's career, two further cases have been identified, namely Mercedes Aldalur (Chascomús) and Ileana Lascaray (Neuquén). The three of them were single women, graduated as primary school teachers, worked in provincial cities where they also participated in civil societies, wrote and developed educational projects that transcended the boundaries of the school activity.

Pedagogical sciences and teaching allowed women from the urban petite bourgeoisie to achieve a certain degree of economic and intellectual emancipation and to get their own legitimate space to exert power creatively and

HoST - Journal of History of Science and Technology 10, pp. 11-32 DOI $10.1515 /$ host-2016-0002 
innovatively. School practices from the first half of the twentieth century fostered scientific training among teachers and children, instructing them in the established protocol of material collection on the field, inventory, cataloguing and exhibition. In addition, the progressive pedagogic perspective derived from "Escuela Nueva" encouraged contact between the school and its natural and social environment. Undoubtedly, the three teachers gained expertise in this educational experience, which enabled them to go beyond the institutional space, mainly female, and to act in a socially broader one, almost exclusively dominated by men. The participation and role of women in the constitution of expert groups that gradually became officers in the new state agencies, proved to be extraordinary and unprecedented. The three women were members of various social networks and simultaneously established partially horizontal and asymmetric relations. Their teaching identity set their profile as civil servants, which distinguished them in this collective of amateurs and collectors.

Nevertheless, it is necessary to mention that this study highlights the importance of further research into the role of women in the compilation of archaeological and natural science collections. Therefore, it is highly stimulating to move forward in the search for and analysis of information repositories that enable access to public and private correspondence. This means of communication set a space of intersection between worlds, proving how the exchange of letters fostered vocational training of amateur scientists from provincial cities, the gender relationships established in that diverse collective, and the constitution of technical groups for state administration.

Although correspondence and the sociability networks that letter-writing exchange facilitated has been a privileged subject of study in the field of history of science, the type of document analysed in this work has not been widely used for the history of scientific practices in Argentina. The discovery and retrieval of such documentation will provide further information regarding local conditions of scientific activity, the role of women and gender relations in that field. 